\title{
BENS PÚBLICOS NO DIREITO BRASILEIRO: UMA ANÁLISE SOB A PERSPECTIVA DAS FUNÇÕES SOCIAL E ECONÔMICA DA PROPRIEDADE PÚBLICA
}

\author{
José Sérgio da Silva Cristóvam ${ }^{1}$ \\ Eduardo Junqueira Bertoncini
}

\section{RESUMO:}

O artigo aborda a temática dos bens públicos no ordenamento jurídico-administrativo brasileiro, com o objetivo de identificar os pontos de relevo da abordagem econômica e das utilidades dos bens, com base nas funções social e econômica da propriedade pública. Temos um cenário dinâmico, que exige uma análise multidisciplinar da gestão pública. $\mathrm{O}$ estudo conclui pela gestão dos bens públicos com base nos critérios da função social e econômica, assim como pelo relevante valor das suas respectivas utilidades. O método utilizado é o dedutivo e monográfico e a técnica de pesquisa bibliográfica, com análise da legislação relacionada e da doutrina sobre o tema.

Palavras-chave: Bens públicos. Função social da propriedade pública. Função econômica dos bens públicos. Utilidades.

\section{PUBLIC GOODS IN BRAZILIAN LAW: AN ANALYSIS FROM THE PERSPECTIVE OF THE SOCIAL AND ECONOMIC FUNCTIONS OF PUBLIC PROPERTY}

\begin{abstract}
:
The article address the theme of public goods in Brazilian legal-administrative system, with the aim of identifying the salient points of the economic approach and the utilities of goods, based on the social and economic functions of public property. We have a dynamic scenario that requires a multidisciplinary analysis of public management. The study concludes by the management of public goods based on the criteria of social and economic function, as well as the relevant value of their respective utilities. The method and technique used are, respectively, the deductive and monographic, and the bibliographic research, with the analysis of related legislation and the doctrine about the subject.
\end{abstract}

\footnotetext{
${ }^{1}$ Professor Adjunto de Direito Administrativo no Curso de Graduação em Direito e no Programa de Mestrado e Doutorado do PPGD/UFSC. Doutor em Direito Administrativo pela UFSC (2014), com estágio de Doutoramento Sanduíche junto à Universidade de Lisboa - Portugal (2012). Mestre em Direito Constitucional pela UFSC (2005). Membro fundador e Presidente do Instituto Catarinense de Direito Público (ICDP). Membro fundador do Instituto de Direito Administrativo de Santa Catarina (IDASC). Membro efetivo do Instituto dos Advogados de Santa Catarina (IASC). Conselheiro Federal da OAB/SC. Presidente da Comissão Especial de Direito Administrativo da OAB Nacional. Presidente da Comissão de Acesso à Justiça da OAB/SC. Membro da Comissão de Direito Constitucional da OAB/SC. Coordenador do Grupo de Estudos em Direito Público do CCJ/UFSC (GEDIP/CCJ/UFSC). http://orcid.org/0000-0001-8232-9122. E-mail: jscristovam@gmail.com

${ }^{2}$ Mestrando em Direito Administrativo pela UFSC. Bacharel em Direito pela UFSC (2018). Membro do Grupo de Estudos em Direito Público do CCJ/UFSC (GEDIP/CCJ/UFSC). Advogado em Santa Catarina. E-mail: ejbertoncini@gmail.com
} 
Keywords: Public goods. Social function of public property. Economic function of public goods. Utilities.

\section{Introdução}

Nas últimas décadas, mais especialmente pós Constituição de 1988, o Direito Administrativo brasileiro tem se deparado com diversos desafios. A conjuntura política, econômica e social demanda novas respostas do regime jurídico-administrativo, com reflexos nas mais variadas matérias. Inclusive, é possível dizer que já não se percebem com tamanha nitidez aquelas clássicas fronteiras entre os diferentes ramos da seara jurídica, atualmente marcada pelo indelével traço da interdisciplinaridade e de uma dinâmica ordem de aproximação/interconexão.

É nesse cenário que se insere a análise do clássico instituto jurídico dos bens públicos. Muito já se discutiu a respeito, especialmente sobre questões históricas, a exemplo da usucapião e da ocupação do solo, assuntos importantes na consolidação das suas bases e desenho normativo do direito pátrio.

Apesar disso, ainda se mostra relativamente raro um olhar contemporâneo sobre essa temática, especialmente de forma a analisar as questões relacionadas ao uso, função e seus aspectos econômicos, objeto do presente estudo.

Sobre a estrutura do artigo, este se divide em três partes, que podem ser sintetizadas nos seguintes objetivos específicos: (i) recuperar breves considerações históricas sobre os bens públicos; (ii) discutir as bases para um conceito de bens públicos, mais apurado e adequado às exigências dos princípios constitucionais da função social, eficiência, economicidade e sustentabilidade; (iii) promover a análise das questões funcionais e financeiras que englobam a questão dos bens públicos, em especial no tocante ao patrimônio imobiliário do Estado.

Cumpre ressaltar que o intuito central do estudo está em discutir a temática sob um prisma garantidor de dois relevantes pontos para a Administração Pública, por meio da análise de seu patrimônio: (i) a qualidade e ampliação da prestação dos serviços públicos e o cumprimento das funções constitucionais; (ii) a geração de receita e o equilíbrio financeiro do Poder Público. 
Com efeito, estas são questões importantes não apenas pela discussão teórica, mas também pela relevância das consequências provocadas no desenvolvimento da Sociedade e no andamento das atividades estatais, inclusive e principalmente num momento em que tanto se debate acerca da centralidade da ideia de sustentabilidade em suas múltiplas dimensões.

\section{Bens públicos: breve recuperação histórico}

A matéria dos bens públicos alcança uma enormidade de coisas/situações que muitas vezes podem passar despercebidas aos cidadãos em geral. Diariamente, todos nos deparamos e relacionamos com diversas categorias e funções dos bens públicos. Estradas, praias, parques, praças, sedes de órgãos públicos - os exemplos são os mais diversos.

Nada obstante, apesar de ser um assunto de forte presença prática, diversos desdobramentos ainda encontram um caminho incerto. Por isso, para melhor compreensão da temática, necessária uma breve recuperação histórica.

Para essa espécie de incursão genealógica resumida, cumpre recuperar que os bens públicos já eram referenciados no Direito romano, com a divisão entre res communes (mares, rios, portos), res publicae (terras, escravos, de propriedade de todos) e res universitatis (ruas, praças, fórum). ${ }^{3}$

O surgimento da República romana trouxe a separação entre o poder religioso e o político, com a divisão entre os bens dedicados às respectivas atividades, sendo o ager publicus o grupo de bens separados dos religiosos e pertencentes coletivamente ao povo. ${ }^{4}$

Conforme bem explica Maria Sylvia Zanella DI PIETRO, o instituto jurídico dos bens públicos evoluiu ao longo do tempo, passando pela Idade Média, em que havia a marcante figura do Rei ou Príncipe detentor do patrimônio estatal, até chegar a noções mais próximas daquelas que temos hoje, com o Estado moderno $^{5}$ e o conceito de Estado como pessoa jurídica, proprietário dos bens públicos. ${ }^{6}$

\footnotetext{
${ }^{3}$ Sobre o tema, ver: DI PIETRO, Maria Sylvia Zanella. Direito administrativo. 29. ed. Rio de Janeiro: Forense, 2016. p. 815.

${ }^{4}$ Sobre o tema, ver: MARQUES NETO, Floriano de Azevedo. Bens públicos: função social e exploração econômica: o regime jurídico das utilidades públicas. Belo Horizonte: Fórum, 2014. p. 61.

${ }^{5}$ Apenas para ilustrar, sobre a questão das noções de lei, justiça e Direito do Medievo e da Modernidade, o jurista e historiador do Direito Paolo GROSSI faz uma interessante e profunda análise crítica do Estado moderno e do papel do Direito na Modernidade, que estaria intimamente vinculado ao poder político, como comando hierarquizado de um superior a um inferior, a partir de uma regra jurídica fundada na autoridade. Uma noção que abandona a dimensão sapiencial do Direito, do justo, do razoável, da razão enquanto medida do real, limitandose a uma forte e monolítica expressão da juridicidade, a lei. A lei dos modernos é antes ato de vontade (autoridade legislativa) do que ato de conhecimento (sapiência do Direito, justiça). A sua força não está no
} 
Na conjugação normativa da Modernidade, pode-se buscar a divisão de bens entre domínio público e privado a partir do Código Civil de Napoleão, de 1804, sendo que tal diploma legal contemplava a distinção entre os bens passíveis ou não de alienação. ${ }^{7}$

No Brasil, a ocupação do território no período colonial provocou interessantes repercussões no processo de caracterização dos bens públicos e do patrimônio territorial do Estado. Conforme recupera Floriano de Azevedo MARQUES NETO, em um primeiro momento todo o território era de domínio estatal, constituído pelas terras da Coroa Portuguesa. Há, então, a posterior apropriação privada das terras públicas, sendo que a parcela remanescente formou o patrimônio do Estado. ${ }^{8}$

Inclusive, como exemplo desse processo de apossamento das glebas públicas, Arnoldo WALD relembra que antes da vigência do Código Civil de 1916 era possível a usucapião de bens imóveis dominicais. ${ }^{9}$

Em síntese, pode-se alinhar o enredo da formação do patrimônio imobiliário do Estado em três principais atos: (i) inicialmente, tudo pertencia ao Poder Público; (ii) com o passar do tempo, foi admitida - e de certo modo incentivada com diversas outorgas de posse (preferencialmente àqueles mais próximos do poder!) - a apropriação privada das terras, principalmente em razão da vastidão do território brasileiro; (iii) em decorrência desse processo, o patrimônio imobiliário do Estado passou a ser aquilo que não fora apropriado pelos particulares.

Essa trajetória da evolução dos bens públicos, especialmente no Brasil, ajuda a entender o tratamento legal e cultural que essa categoria de bens acaba por receber da nossa

conteúdo (o que é dito), mas no fato de provir do órgão máximo de poder político. A Modernidade teria reduzido o Direito à lei, apartando-o da ideia de justiça. O que "o Estado moderno assegura aos cidadãos é somente um complexo de garantias formais", ou seja, um ato de autoridade formulado com base em determinados procedimentos, onde o seu conteúdo, a correspondência ao que a consciência comum reputa como o justo (a justiça da lei), isso é somente um objetivo exterior do ordenamento jurídico. Nesse sentido: GROSSI, Paolo. Mitologias jurídicas da Modernidade. Tradução de Arno Dal Ri Júnior. Florianópolis: Fundação Boiteux, 2004. p. 13-37. Para o estudo a partir de outra abalizada análise crítica do Direito e sua relação com o Estado, com base em uma matriz historicista, com especial atenção para a crise de legitimidade do discurso jurídico na Modernidade, consultar: ROULAND, Norbert. Nos confins dos Direito: antropologia jurídica da Modernidade. Tradução de Maria Ermantina de Almeida Prado Galvão. São Paulo: Martins Fontes, 2003.

${ }^{6}$ DI PIETRO, Maria Sylvia Zanella. Direito administrativo. 29. ed. Rio de Janeiro: Forense, 2016. p. 816.

7 MARQUES NETO, Floriano de Azevedo. Bens públicos: função social e exploração econômica: o regime jurídico das utilidades públicas. Belo Horizonte: Fórum, 2014. p. 66.

${ }^{8}$ MARQUES NETO, Floriano de Azevedo. Bens públicos: função social e exploração econômica: o regime jurídico das utilidades públicas. Belo Horizonte: Fórum, 2014. p. 89-91.

${ }_{9}^{9}$ WALD, Arnoldo. Bens públicos: usucapião de imóveis dominicais. Revista de Direito Administrativo, Rio de Janeiro, v. 101, n. 1, p.378-382, jan. 1970. Disponível em: http://bibliotecadigital.fgv.br/ojs/index.php/rda/article/view/34519. Acesso em: 20 dez. 2019. 
Sociedade. A característica de remanescência, ao mesmo tempo em que configura um patrimônio - principalmente imobiliário - extenso, pode indicar a tônica de certa dimensão de descuido e até descaso em relação aquilo que não nos pertence individualmente, um pensamento a um só tempo indesejado e que precisa ser rechaçado/superado mormente sob o primado multidimensional da sustentabilidade e do desenvolvimento sustentável.

\section{Conceito e classificação dos bens públicos no Direito brasileiro}

Em relação aos reflexos no âmbito do Direito brasileiro, a primeira classificação dos bens públicos na legislação foi disposta no Código Civil de 1916, numa dimensão normativa básica que foi mantida pelo artigo 98 do Código Civil de $2002,{ }^{10}$ com o prestígio do critério subjetivo (definição que leva em conta quem é o proprietário). Nesta esteira, a partir desse forte componente subjetivo, José dos Santos CARVALHO FILHO conceitua bens públicos como "todos aqueles que, de qualquer natureza e a qualquer título pertençam às pessoas de direito público". ${ }^{11}$

DI PIETRO avança para defender a possibilidade de distinguir duas modalidades de bens públicos, classificadas de acordo com a respectiva destinação: os bens do domínio público do Estado (afetados - uso comum e uso especial); e os bens do domínio privado do Estado (dominicais - segundo a autora aqueles sem destinação). ${ }^{12}$

No mesmo sentido parecem sustentar André SADDY e Emerson MOURA, para quem a definição de domínio público recai sobre dois critérios, a titularidade do bem pela Administração Pública e a sua afetação, ao passo que os bens de domínio privado ou patrimonial seriam aqueles de titularidade do ente público mas sem afetação, com uma função econômica de geração de renda para o Estado. ${ }^{13}$

Por outro lado, o fato dessa estrutura de "certidão de nascimento" do instituto dos bens públicos ser advinda do direito civil traz alguns percalços para seu estudo no âmbito do regime jurídico-administrativo. É que a definição de bens públicos formulada sob o enfoque

\footnotetext{
${ }^{10}$ Neste sentido: “Art. 98. São públicos os bens do domínio nacional pertencentes às pessoas jurídicas de direito público interno; todos os outros são particulares, seja qual for a pessoa a que pertencerem".

${ }^{11}$ CARVAlHO FILHO, José dos Santos. Manual de direito administrativo. 26. ed. rev., ampl. e atual. São Paulo: Atlas, 2013. p. 1139.

12 DI PIETRO, Maria Sylvia Zanella. Direito administrativo. 29. ed. Rio de Janeiro: Forense, 2016. p. 817.

${ }^{13}$ SADDY, André; MOURA, Emerson. A natureza jurídica dos bens das empresas estatais brasileiras: análise da controvérsia acerca do controle dos recursos repassado. Revista Digital de Derecho Administrativo, n. 22, p. 141-161, jul./dic. 2019. p. 143-145. Disponível em: https://papers.ssrn.com/sol3/papers.cfm?abstract_id=3413771. Acesso em: 20 dez. 2019.
} 
da lógica civilista parece insuficiente, porquanto se preocupa exclusivamente em saber quem é o sujeito do direito subjetivo de propriedade, ao passo que o direito público precisa voltar-se para o emprego destes bens. No panorama civil, há o foco na titularidade, no domínio, ao tempo em que a ótica jurídico-administrativa está centrada na dimensão funcional, pelo que releva perquirir acerca do "emprego do bem no cumprimento de uma finalidade do Estado". ${ }^{14}$

Sobre a dimensão funcionalista, SADDY e MOURA advertem que o bem pode ser considerado público mesmo que não pertença à uma pessoa jurídica de direito público, pois o que deve ser levado em conta é sua afetação à prestação de um serviço público. Seria o caso, $v$. $g$. de bens pertencentes a sociedades de economia mista prestadoras de serviço público. ${ }^{15}$

Esse entendimento acarreta reflexos na utilização prática do bem, eis que impõe (em maior ou menor grau) a obediência a normas de direito público aplicáveis à espécie. Há, assim, certa mitigação das características de direito privado que garantiriam ampla autonomia de gestão do bem pela empresa prestadora de serviço público.

Com efeito, extrai-se da lição de MARQUES NETO que "o regime de direito público aplicável aos bens públicos tem premissas diferentes, pois não se limita à relação jurídica entre o sujeito (proprietário) e a coisa, abrangendo também a finalidade (utilidade) que o bem deve ter". 16

Contudo, importa ressaltar que os critérios subjetivo (civilista) e objetivo (administrativista) não se excluem, antes indicam sim uma ordem de complementariedade, no sentido de reconhecer o traço subjetivo do Poder Público como proprietário; e, também, indicam a definição da gestão, uso, aquisição e alienação dos bens públicos pela lógica da dimensão funcional-administrativa.

Até porque a adoção indiscriminada da concepção funcionalista (critério objetivo) também pode acarretar problemas. Seria o caso, por exemplo, de um bem pertencente a uma pessoa jurídica de direito privado, submetido ao regime publicista, que teria a subtração das prerrogativas da propriedade privada, simplesmente em razão de estar empregado na

\footnotetext{
${ }^{14}$ MARQUES NETO, Floriano de Azevedo. Bens públicos: função social e exploração econômica: o regime jurídico das utilidades públicas. Belo Horizonte: Fórum, 2014. p. 102-103.

${ }^{15}$ SADDY, André; MOURA, Emerson. A natureza jurídica dos bens das empresas estatais brasileiras: análise da controvérsia acerca do controle dos recursos repassado. Revista Digital de Derecho Administrativo, n. 22, p. 141-161, jul./dic. 2019. p. 145-146. Disponível em: https://papers.ssrn.com/sol3/papers.cfm?abstract_id=3413771. Acesso em: 20 dez. 2019.

${ }^{16}$ MARQUES NETO, Floriano de Azevedo. Bens públicos: função social e exploração econômica: o regime jurídico das utilidades públicas. Belo Horizonte: Fórum, 2014. p. 115.
} 
prestação de um serviço público, como na hipótese de um imóvel privado alugado para servir como sede de determinado órgão governamental. ${ }^{17}$

A classificação funcional ou finalista dos bens públicos está intimamente ligada ao conceito de afetação, ou seja, a "consagração do bem a uma utilização concernente a uma utilidade pública", com a submissão do respectivo bem a algum uso específico da Administração Pública. ${ }^{18}$

Sobre o tema, cumpre lembrar que a afetação pode ser tácita ou expressa, e tem incidência pacífica tanto sobre os bens de uso comum quanto sobre aqueles de uso especial. Já com relação aos bens dominicais, a afetação é mais controversa. Há quem entenda que tal categoria de bens públicos não possue afetação por não estar diretamente ligada a algum uso. $^{19}$

Nada obstante, parece mais acertado o entendimento de que tais bens possuem uma espécie de afetação/aplicação remota ou mediata, na medida em que os bens dominicais devem servir para gerar receitas à Administração Pública. Estariam esses bens, assim, destinados não a uma função específica do Poder Público ou algum uso direto comum a todos os indivíduos, mas sim num caráter de instrumentalidade da ação estatal, no sentido de conferir condições financeiras ao ente público para o cumprimento dos deveres prestacionais. $^{20}$

Esse papel de geração de receitas desempenhado pelos bens públicos dominicais é fundamental para atender aos princípios da função social da propriedade, da economicidade, da eficiência e da sustentabilidade, todos designados a afastar a ociosidade e consequente desperdício de bens.

Ainda sobre a afetação ou destinação, Amauri Feres SAAD explica que é a dimensão condicionante das outras duas dimensões da gestão patrimonial do Estado, pois determina se e quando estas deverão ocorrer: a aquisição e a alienação. Portanto, a função do bem ou a

\footnotetext{
${ }^{17}$ MARQUES NETO, Floriano de Azevedo. Bens públicos: função social e exploração econômica: o regime jurídico das utilidades públicas. Belo Horizonte: Fórum, 2014. p. 120.

${ }_{18}$ MARQUES NETO, Floriano de Azevedo. Bens públicos: função social e exploração econômica: o regime jurídico das utilidades públicas. Belo Horizonte: Fórum, 2014. p. 121.

${ }^{19}$ DI PIETRO, Maria Sylvia Zanella. Direito administrativo. 29. ed. Rio de Janeiro: Forense, 2016. p. 819.

${ }^{20}$ MARQUES NETO, Floriano de Azevedo. Bens públicos: função social e exploração econômica: o regime jurídico das utilidades públicas. Belo Horizonte: Fórum, 2014. p. 221.
} 
ausência de função é fator determinante para que a Administração Pública decida por, respectivamente, adquiri-lo ou aliená-lo. ${ }^{21}$

Importa ressaltar que a proximidade dos conceitos de afetação e função é importante para compreender as razões de existência dos bens públicos. Não se firma a hipótese de subsistir um patrimônio estatal, em especial imobiliário, apenas como reserva de riqueza, sem que seja conferida alguma utilidade.

Os bens públicos existem para que o Estado possa realizar suas funções, seja por meio do uso direto do bem na prestação de algum serviço público, seja por meio da arrecadação de receitas para custear suas atividades prestacionais. A riqueza, nesse sentido, deve sempre permanecer e ter como foco a coletividade de indivíduos, somente sendo albergada nas mãos do Poder Público para os fins das suas funções constitucionalmente definidas. Esse é o foco, o desiderato e mesmo a vocação legitimadora do Estado - servir a Sociedade; e não dela se servir!

Nessa linha de pensamento, pode-se construir um conceito de bens públicos como aqueles bens (em sentido amplo) pertencentes ao Estado, empregados em alguma atividade que traduza utilidades aos cidadãos (prestação de serviços públicos, desenvolvimento das suas atividades finalísticas, promoção de políticas públicas etc.), seja por meio do uso direto, indireto ou geração de receitas.

Adiante, necessário discutir acerca dos principais aspectos dessa concepção: o desenvolvimento da função social da propriedade pública e da função econômica dos bens públicos.

\section{A função social da propriedade pública}

A noção de função social da propriedade privada parte da flexibilização/superação da antiga concepção de propriedade privada como conceito absoluto, oponível sem restrições e como limite ao Estado, um direito individual. Apesar disso, conforme explica José Afonso da SILVA, a função social não se confunde com os sistemas de limites da propriedade, pois estes tratam do exercício do direito, ao passo que aquela relaciona-se à própria estrutura do direito,

\footnotetext{
${ }^{21}$ SAAD, Amauri Feres. Permuta de bens públicos imóveis. Revista de Direito Administrativo, Rio de Janeiro, v. 265, p.111-147, jan. / abr. 2014. p. 113. Disponível em: http://bibliotecadigital.fgv.br/ojs/index.php/rda/article/view/18914. Acesso em: 20 dez. 2019.
} 
constituindo o fundamento do regime jurídico da propriedade, com um novo interesse que não se confunde com o do proprietário, um interesse coletivo. ${ }^{22}$

Assim, a função social da propriedade projeta o caráter coletivo, suplantador da noção individualista focada na figura do proprietário, refletindo nos seus desdobramentos sociais. A propriedade, desse modo, não pode prejudicar aspectos da coletividade, como organização urbana, aproveitamento espacial, manutenção do bem e a própria sustentabilidade. De acordo com Nilma de Castro ABE, a função social da propriedade consiste em verdadeiro:

[...] dever de cumprir um destino economicamente útil, produtivo, de maneira a satisfazer às necessidades sociais preenchíveis pela espécie do bem (ou pelo menos não poderá ser utilizada de modo a contraditar esses interesses), de modo que o bem deve cumprir a exata funcionalidade que dele se espera em proveito da coletividade. ${ }^{23}$

Disposta na Constituição de 1988, no inciso XXIII do artigo $5^{\circ}$, no artigo 170 , III e no artigo 182, $\S 2^{\circ}$, a função social da propriedade configura-se no âmbito dos direitos e deveres individuais e coletivos, perfazendo efetivo dever fundamental. Também, não há distinção constitucional sobre a aplicação do mandamento "a propriedade atenderá a sua função social" às propriedades privadas ou públicas. Esse silêncio constitucional, a princípio, conduziria ao entendimento de que é aplicável tanto a uma quanto a outra espécie de propriedade.

Contudo, há autores que discordam da existência da função social da propriedade pública. Um dos fundamentos apresentados para sustentar tal argumentação é a impossibilidade de impor sanções ao ente público que descumprir a função social da propriedade. Neste sentido:

Observa-se que, enquanto dever fundamental, a função social da propriedade, previsto no art. 5. ${ }^{\circ}$, XXIII, da Constituição Federal, deve ser atendida por todos os particulares e, não pelo Estado, pois as sanções jurídicas previstas para o descumprimento da função social da propriedade urbana são imputáveis apenas aos particulares, sendo inadequadas para punir os entes públicos (União, Estados, DF, Municípios) pelo descumprimento deste dever. ${ }^{24}$

\footnotetext{
${ }^{22}$ SILVA, José Afonso da. Curso de direito constitucional positivo. 32. ed. rev. e atual. São Paulo: Malheiros, 2009. p. 281-283.

${ }^{23}$ ABE, Nilma de Castro. Notas sobre a inaplicabilidade da função social à propriedade pública. Revista Brasileira de Direito Constitucional, n. 11, jun. 2008. p. 6. Disponível em: http://bdjur.stj.jus.br/dspace/handle/2011/34731. Acesso em: 20 dez. 2019.

${ }^{24}$ ABE, Nilma de Castro. Notas sobre a inaplicabilidade da função social à propriedade pública. Revista Brasileira de Direito Constitucional, n. 11, jun. 2008. p. 7. Disponível em: http://bdjur.stj.jus.br/dspace/handle/2011/34731. Acesso em: 20 dez. 2019.
} 
Nada obstante, a inaplicabilidade de sanção não parece capaz de afastar a dimensão de função social da propriedade pública. Isso porque referido conceito preceitua uma série de procedimentos e medidas a serem adotadas e promovidas pelos proprietários, com intuito de conferir um senso de coletividade à propriedade. Ora, se a dimensão da função social é oponível em face da propriedade privada, em favor da coletividade, com muito mais razão deve ser em face da propriedade pública - já que ao Estado incumbe, por excelência, a defesa dos interesses da coletividade (interesse público em sentido amplo). ${ }^{25}$ Até porque se afirma ser inerente às propriedades públicas essa noção de interesse coletivo, esse é um traço de confirmação da aplicação à espécie da dimensão político-normativa da função social, que caso descumprida não ensejará as mesmas sanções impostas aos particulares, mas pode eventualmente configurar desvio de finalidade. ${ }^{26}$ Nesse mesmo sentido:

[...] a aplicação do princípio da função social da propriedade pública é um remédio eficaz, tanto no sentido de ser mais um instrumento para coibir o desvio de finalidade e de garantir uma otimização da utilização do bem público, no sentido de se extrair desses bens o melhor benefício possível, levando-se em consideração não apenas o interesse público, mas acima de tudo o interesse social. Nesse último caso, a função social da propriedade pública age como um comando otimizador da discricionariedade do administrador público, com um conteúdo específico acerca dos bens de domínio público. ${ }^{27}$

Logicamente, não é a função social da propriedade o único mandamento que exige essa postura dos proprietários, quer com relação aos bens públicos quer sobre os privados. Justo por essa razão, descabe o argumento de que não seria aproveitável na esfera pública, em virtude do regime jurídico-administrativo já possuir uma série de princípios próprios que reforçam esse comportamento solidário. Até porque, no âmbito privado também existem

\footnotetext{
${ }^{25}$ Ultrapassam os limites desse estudo o debate mais aprofundado sobre o conceito de interesse público e sua centralidade para o regime jurídico-administrativo. Apenas em breves considerações, pode-se dizer que o "conceito de interesse público confunde-se com os valores indisponíveis assegurados pela Constituição, sob o signo inafastável dos direitos fundamentais e da centralidade do princípio da dignidade da pessoa humana (personalização da ordem constitucional)". Sobre a noção de interesse público, ver: CRISTÓVAM, José Sérgio da Silva. Administração Pública democrática e supremacia do interesse público: novo regime jurídicoadministrativo e seus princípios constitucionais estruturantes. Curitiba: Juruá, 2015. p. 98-117.

${ }^{26}$ Sobre o tema, ver: DI PIETRO, Maria Sylvia Zanella. Função social da propriedade pública. Revista Eletrônica de Direito do Estado. Salvador: Instituto de Direito Privado da Bahia, ${ }^{\circ}$ 6, abril $/ \mathrm{maio} / \mathrm{junho} \mathrm{de}$ 2006. Disponível em: http://www.direitodoestado.com.br/codrevista.asp?cod=104. Acesso em: 20 dez. 2019.

${ }^{27}$ REIS, João Emilio de Assis. A função social da propriedade e sua aplicabilidade sobre bens públicos. XXI Encontro Nacional do CONPEDI, 2012, Uberlândia. Anais do XXI Encontro Nacional do CONPEDI. p. 18. Disponível em: http://www.publicadireito.com.br/artigos/?cod=4d5b995358e7798b. Acesso em: 20 dez. 2019.
} 
outras normas a exigir a conduta de senso coletivo dos proprietários, e nem por isso se afasta a incidência da função social da propriedade.

Nesse sentido, pode-se definir a função social da propriedade pública como um mandamento geral, de reforço das demais normas e princípios regentes do regime jurídicoadministrativo, no sentido de conferir a obrigação aos entes públicos de promover a adequada destinação dos seus bens, inclusive com a especial observância do Plano Diretor e demais normas urbanísticas, do aproveitamento de ocupação dos imóveis, das práticas sustentáveis etc. $^{28}$

De certa forma, a função social da propriedade pública pode ensejar um caráter de pleonasmo no primeiro momento, em razão da própria obrigação da Administração Pública estar vinculada aos fins de bem-comum. Contudo, apesar de não ser tão clara quanto a função social da propriedade privada, tal dimensão normativa também é agasalhada no âmbito público pela Constituição. ${ }^{29}$

Inegavelmente, a esfera em que mais se percebe a aplicação da função social da propriedade pública é a do direito urbanístico, em que há um direito coletivo de se exigir a observância da norma constitucional do art. 182 e das previsões do Estatuto da Cidade. Ademais, a função social da propriedade pública determina a ampliação, sempre que possível, das modalidades de uso dos bens públicos de uso comum e especial. Assim, desde que não haja prejuízo à afetação precípua daquele bem, devem ser buscadas outras formas de aproveitamento dos respectivos bens públicos. ${ }^{30}$

O cumprimento da função social da propriedade pública está diretamente ligado ao uso daquele bem. É o que resta claro da lição de MARQUES NETO, quando ensina que "para o atendimento pleno da função social do bem há que se perquirir se o emprego específico a ele dado corresponde à melhor utilidade que dele se pode extrair". Como consequência, o autor defende que um bem dominical, por exemplo, não atende à função social só pelo fato de

\footnotetext{
${ }^{28}$ Sobre o tema, ver: CRISTÓVAM, José Sérgio da Silva; PRIESS, Alexandre dos Santos. O Plano Diretor como instrumento de planificação das cidades: uma análise das consequências jurídicas da sua não revisão e os eventuais impactos da Lei n. ${ }^{\circ}$ 13.655/18 (LINDB). In. VALIATI, Thiago Priess; HUNGARO, Luis Alberto; CASTELLA, Gabriel Morettini e. A Lei de Introdução e o direito administrativo brasileiro. Rio de Janeiro: Lumen Juris, 2019. p. 569-594.

${ }^{29}$ DI PIETRO, Maria Sylvia Zanella. Função social da propriedade pública. Revista Eletrônica de Direito do Estado. Salvador: Instituto de Direito Privado da Bahia, $\mathrm{n}^{\circ}$ 6, abril/maio/junho de 2006. p. 1-2. Disponível em: http://www.direitodoestado.com.br/codrevista.asp?cod=104. Acesso em: 20 dez. 2019.

${ }^{30}$ DI PIETRO, Maria Sylvia Zanella. Função social da propriedade pública. Revista Eletrônica de Direito do Estado. Salvador: Instituto de Direito Privado da Bahia, $\mathrm{n}^{\circ}$ 6, abril/maio/junho de 2006. p. 4-9. Disponível em: http://www.direitodoestado.com.br/codrevista.asp?cod=104. Acesso em: 20 dez. 2019.
} 
pertencer ao Estado. Para tanto, deve estar empregado em alguma finalidade, podendo até mesmo ser utilizado como fonte de geração de receita para a Administração Pública. ${ }^{31}$

Um imóvel público subaproveitado não atende de forma plena a sua função social. Caso seja possível, e houver motivação fundamentada, a alienação desse imóvel, a sua alienação parcial ou, ainda, a afetação do bem a mais de um uso, inclusive na concretização dos interesses sociais albergados pela Constituição de 1988 (infraestrutura de serviços públicos, promoção de políticas públicas etc.), possibilitará um incremento no aproveitamento da área, com consequente prestígio a função social da propriedade, pois será dado um melhor destino há algo que pertence à coletividade.

Apenas para exemplificar, se esse uso do imóvel ou de parte do imóvel por um particular for para algo que venha a atender uma deficiência da localidade, como um hotel sobre uma estação de ônibus/trem que não possuía nas redondezas tal infraestrutura, a função social da propriedade será então maximizada. O mesmo se pode dizer do uso para a ampliação de serviços públicos e fomento a áreas como educação, ciência, cultura, moradia etc.

Nesse sentido, devem ser aproveitadas todas as utilidades suportáveis e conciliáveis pelo bem, para que sejam atendidos dois objetivos: (i) a otimização do bem em benefício da coletividade; (ii) a rentabilização dos bens, por meio do seu aproveitamento econômico, que deve ser voltado ao custeio das atividades estatais, desde que não interfira negativamente sobre a finalidade primária do bem. ${ }^{32}$

\section{A função econômica dos bens públicos imóveis}

Conforme restou debatido, a função social da propriedade pública é um desdobramento inerente à própria noção de bens públicos. É, por assim dizer, o emprego da propriedade pública de acordo com a sua razão de existência legítima.

Outra dimensão que evidencia a razão de ser dos bens públicos pode decorrer da função econômica. Se, por um lado, há uma necessidade evidente, consagradora dos princípios constitucionais, na utilização do patrimônio público de forma lúcida, eficaz, sustentável e inclusiva, como instrumento de prestação dos serviços públicos e desenvolvimento das funções estatais, por outro há um aspecto inafastável e que decorre da

\footnotetext{
${ }^{31}$ MARQUES NETO, Floriano de Azevedo. Bens públicos: função social e exploração econômica: o regime jurídico das utilidades públicas. Belo Horizonte: Fórum, 2014. p. 396-397.

${ }_{32}$ MARQUES NETO, Floriano de Azevedo. Bens públicos: função social e exploração econômica: o regime jurídico das utilidades públicas. Belo Horizonte: Fórum, 2014. p. 397-399.
} 
ordem constitucional estabelecida em sintonia com a Sociedade contemporânea: a função econômica.

Esse caráter de dupla face é bem explicado por MARQUES NETO, para quem:

\begin{abstract}
A gestão dos bens públicos envolve dois aspectos inter-relacionados: a gestão patrimonial, entendida como a otimização do emprego do patrimônio público, com vistas a obter a maior racionalidade econômica, e a disciplina do uso, voltada a assegurar que este emprego seja consentâneo com as finalidades de interesse geral aos quais o bem está consagrado. É da combinação destes dois aspectos que se dá a adequada gestão dos bens públicos. ${ }^{33}$
\end{abstract}

Na mesma toada, o autor desenvolve a questão da afetação múltipla, que conceitua como possibilidade de se instituir mais de uma afetação quando "o bem comportar usos distintos, permanentes e compatíveis entre si". 34

Essa possibilidade de múltiplos usos dos bens públicos deve ser prestigiada, porquanto permite o melhor aproveitamento daquele patrimônio. Este também parece ser o entendimento de DI PIETRO, quando defende que "os bens públicos devem ser disciplinados de tal forma que permitam proporcionar o máximo de benefícios à coletividade, podendo desdobrar-se em tantas modalidades de uso quantas forem compatíveis com a destinação e com a conservação do bem". ${ }^{35}$

Cumpre destacar, do que restou até aqui defendido, que a relevância do bem está no seu uso (ou, para ser mais exato, nos seus usos), o que permite considerar que o valor do bem público está diretamente ligado a sua utilidade. Por isso, incumbe a Administração Pública gerir seu patrimônio de forma efetiva, eficiente e sustentável, como verdadeira proprietária, e não se limitar ao mero poder de guarda/conservação. Assim, admite-se a multiplicidade de usos e os diversos empregos econômicos concernentes às aplicações, de maneira a incentivar a gestão dinâmica em lugar da improdutividade e ociosidade estática. ${ }^{36}$

Com efeito, o caráter marcante da utilidade dos bens públicos movimenta o seu centro de valor. De acordo com MARQUES NETO, há um crescente processo de desmaterialização

\footnotetext{
${ }^{33}$ MARQUES NETO, Floriano de Azevedo. Bens públicos: função social e exploração econômica: o regime jurídico das utilidades públicas. Belo Horizonte: Fórum, 2014. p. 270.

${ }_{34}$ MARQUES NETO, Floriano de Azevedo. Bens públicos: função social e exploração econômica: o regime jurídico das utilidades públicas. Belo Horizonte: Fórum, 2014. p. 287.

${ }_{35}$ DI PIETRO, Maria Sylvia Zanella. Direito administrativo. 29. ed. Rio de Janeiro: Forense, 2016. p. 287.

${ }^{36}$ MARQUES NETO, Floriano de Azevedo. Bens públicos: função social e exploração econômica: o regime jurídico das utilidades públicas. Belo Horizonte: Fórum, 2014. p. 386.
} 
da propriedade e da riqueza, o que confere um deslocamento do valor dos bens materiais para os bens intangíveis, que passam a ter maior importância econômica. ${ }^{37}$

Esse processo pode ser percebido principalmente no setor privado, nas avaliações de ativos empresariais e na nova economia digital, em que empresas valiosíssimas possuem seu capital intelectual e capacidade de inovação como maior ativo. Embora existam situações em que a empresa seja avaliada pelo patrimônio físico (instalações, estoque, maquinário etc.), a cada dia ganha destaque a capacidade de gerar receitas pelos conhecimentos técnicos e mercadológicos daquele corpo empresarial.

No âmbito do direito público, essa modificação valorativa pode ser percebida na relevância das utilidades dos bens em detrimento do seu mero valor de troca. $\mathrm{O}$ uso do bem público é muito mais importante do que seu valor de comercialização, justamente pela função que deve exercer, de modo a não se justificar o patrimônio público estático como reserva de valor.

Diante de um cenário de escassez de recursos, também são escassas as utilidades, eis que oriundas de um processo decisório do gestor público, no sentido de eleger prioridades, o que leva, já numa análise da consequência, a uma união das utilidades e da implementação de políticas públicas. Partindo desse ponto que confere relevo ao uso do bem, MARQUES NETO desenvolve quatro critérios a serem adotados pela Administração Pública para a identificação e definição das utilidades prevalecentes no uso de um determinado bem:

(i) critério da afetação original; (ii) critério da generalidade ou abrangência; (iii) critério da prejudicialidade ou da rivalidade; (iv) critério da economicidade ou da rentabilidade. A aplicação de tais critérios deve ser feita sempre na ordem da sequência apresentada, de modo que a prevalência de um uso sempre decorrerá do critério anterior em detrimento do critério posterior. Note-se que a aplicação dos critérios anteriores não significa dizer que um uso excluirá o outro. Eles apenas nos serão úteis para definir o regime jurídico aplicável ao bem de modo a que um uso secundário não obste a plena fruição de um uso primário. ${ }^{38}$

O primeiro critério guarda estreita relação com o princípio da legalidade, ao prever como principal o uso que foi determinado por lei, protegendo a afetação realizada por ato

\footnotetext{
${ }^{37}$ MARQUES NETO, Floriano de Azevedo. Bens públicos: função social e exploração econômica: o regime jurídico das utilidades públicas. Belo Horizonte: Fórum, 2014. p. 389.

${ }^{38}$ MARQUES NETO, Floriano de Azevedo. Bens públicos: função social e exploração econômica: o regime jurídico das utilidades públicas. Belo Horizonte: Fórum, 2014. p. 420.
} 
formal. O segundo critério, por sua vez, impõe que quando houver dois ou mais usos conflitantes entre si, deve prevalecer aquele que seja acessível a um maior universo de cidadãos, com base nos consagrados conceitos de proveito uti universi e uti singuli.

Já o terceiro critério predispõe que seja privilegiado o uso que permita o gozo do maior número de cidadãos ou que se concilie com outros possíveis usos do bem, com o intuito de trazer maior utilidade para a coletividade.

O último critério, a ser levado em conta na hipótese de não ter sido identificado o melhor uso com base na análise dos critérios anteriores, determina o uso que represente a maior arrecadação financeira para a Administração Pública, levando-se em conta, ainda, que o uso econômico de interesse geral prevaleça sobre o uso econômico de interesse particular.

Ante a limitação de utilidades aplicáveis aos bens públicos, apresenta-se a questão da escassez. Nesse sentido, será possível extrair algum valor econômico daquele bem que possui esse uso escasso, logicamente que seguindo os critérios anteriormente mencionados, com o aproveitamento econômico como ponto subsidiário e dentro de parâmetros constitucionais.

Portanto, o aproveitamento econômico pode ser exercido diretamente pelo Estado (obedecidas as normas da exploração econômica estatal, v.g. o art. 173 da CRFB), indiretamente (por meio de outorga do direito ao particular que explorará o bem) ou ainda mediante o valor de troca (alienação), este último em casos específicos.

Para que exista esse aproveitamento econômico, algum ou alguns indivíduos deverão arcar com os custos da utilidade daquele determinado bem. Alguns exemplos são os casos das rodovias concedidas à iniciativa privada, dos aluguéis de imóveis públicos, ou ainda do custeio da ocupação do espaço público para passagem de cabos de energia ou telefonia.

Os objetivos do aproveitamento econômico dos bens públicos podem ser para geração de receitas ao erário, para atração de particulares a dar utilidade ao bem (de interesse geral), ou incentivo ao uso de um bem público ocioso, com vistas ao cumprimento dos princípios da função social e econômica, bem como os aspectos da sustentabilidade. ${ }^{39}$

Com relação aos aspectos sustentáveis, cumpre reafirmar a necessidade de adequação do uso dos bens públicos às acepções ambientais, sociais e econômicas da sustentabilidade, que servem como apoio ao processo decisório da Administração Pública. ${ }^{40}$

\footnotetext{
${ }^{39}$ MARQUES NETO, Floriano de Azevedo. Bens públicos: função social e exploração econômica: o regime jurídico das utilidades públicas. Belo Horizonte: Fórum, 2014. p. 433.

${ }^{40}$ Sobre o tema, ver: FREITAS, Juarez. Sustentabilidade: direito ao futuro. 3. ed. Belo Horizonte: Fórum, 2016; OTERO, Paulo. Manual de direito administrativo. Coimbra: Almedina, 2016.
} 
Por essa razão, importante notar o ponto de acréscimo aos critérios determinantes das utilidades aplicadas aos bens públicos, já mencionados anteriormente: a imperiosidade da noção de sustentabilidade ampla, com suas diversas consequências.

A primeira e clássica acepção, que trata do universo ambiental, tem sua premência destacada pela própria situação ecológica vivenciada no planeta, assim como pelos sombrios prognósticos da vida humana, da flora e da fauna terrestre.

Qualquer atividade praticada pela Administração Pública, aí incluída a gestão dos seus bens, deve guardar coerência com os mandamentos da preservação ambiental, desenvolvimento ecológico sustentável e solidariedade intergeracional, a partir de uma visão realmente preocupada com o futuro.

Inclusive, e de uma maneira mais radical, há algum tempo estudiosos do tema defendem uma ruptura com o atual sistema de desenvolvimento sustentável, que parece ter demonstrado não cumprir suas funções. ${ }^{41}$ Para tanto, seria necessário implementar um novo paradigma pautado do direito ecológico, com o afastamento do caráter antropocentrista e o reconhecimento de direitos dos próprios elementos naturais.

Outra acepção da sustentabilidade desdobra-se no aspecto social. Aqui, há clara relação com o próprio princípio da função social da propriedade, objeto central desse estudo. Prevê, portanto, a valorização da inclusão social, ampliação de políticas públicas e utilidade dos bens públicos conferida de forma ampla aos cidadãos. Em resumo, a previsão desses direitos sociais como condição de possibilidade a um futuro exercício ampliado das gerações vindouras. $^{42}$

A terceira noção de sustentabilidade aqui abordada também guarda estreita proximidade com a questão em debate. É a sustentabilidade econômica, que determina, dentre outros aspectos, atenção à gestão financeira, equilíbrio fiscal, controle de gastos públicos e investimentos que cumpram as funções do Estado sem que haja desperdício. ${ }^{43}$

Em síntese, tudo isso deixa evidente mais um considerável fator de relevo na gestão comprometida dos bens públicos com base nos critérios da utilidade e do aproveitamento

\footnotetext{
${ }^{41}$ Sobre a ruptura do direito ambiental vigente, baseado no antropocentrismo, para um paradigma ecológico, ver: STONE, Christofer D.. Should trees have standing? law, morality and the environment. 3. ed. Oxford: Oxford University Press, 2010.

${ }^{42}$ Para uma análise mais densa sobre a dimensão social da sustentabilidade, bem como as dimensões jurídicopolítica e ética, ver: FREITAS, Juarez. Sustentabilidade: direito ao futuro. 3. ed. Belo Horizonte: Fórum, 2016. p. 62 .

${ }^{43}$ Sobre o tema, ver: OTERO, Paulo. Manual de direito administrativo. Coimbra: Almedina, 2016.
} 
econômico, sendo estes últimos fundamentais para a sustentabilidade das contas públicas e consequente viabilidade das funções estatais ao longo do tempo, privilegiando-se a solidariedade intergeracional.

\section{Conclusão}

A temática dos bens públicos envolve uma série de relevantes aspectos com presença marcante na atividade prática da Administração Pública. Questões referentes à ocupação do espaço urbano, destinação de uso dos bens de propriedade pública, alienação ou aquisição de bens imóveis, aluguel, cessão, enfim, diversos assuntos que possuem reflexos diretos da forma eleita pelo Estado para gestão de seu patrimônio e implementação de políticas públicas.

O nascer e evoluir do conceito de bens públicos no Direito brasileiro, bem como suas disposições legais, revelam uma lógica de sobra/remanescência, que permeia até hoje a relação dos particulares e do próprio Poder Público com essa categoria de bens. Todavia, a recuperação histórica demonstra a necessidade de uma valorização da ideia de patrimônio público, coletivo, que passa a exigir do Estado e de seus agentes maior preocupação, principalmente no sentido de evitar que haja desperdício e patrimônio ocioso.

Em síntese, especialmente em face do dinamismo e desafios impostos pela contemporaneidade, não há mais sentido na existência de um patrimônio de reserva, uma noção antiquada de valor apenas como critério de comercialização do bem (valor de troca). Pior, não raras vezes há situações de bens públicos imóveis que permanecem em abandono, sem uso algum, seja para gerar receitas ou para servir de instrumento de prestação de serviços públicos ou fomento a políticas públicas nas mais variadas áreas de densificação das promessas constitucionais. As necessidades sociais são muitas, as demandas crescentes e expectativas alargadas: a resposta da Administração Pública há de ser rápida, efetiva e concertada.

Nessa linha de raciocínio, o valor de utilidade dos bens públicos surge como ponto determinante da gestão e do processo decisório de afetação. Faz-se imperioso extrair o maior número de utilidades, desde que compatíveis, extensivas ao maior número de cidadãos. Quando isto não for possível, o aproveitamento econômico desponta como provável solução, permitindo aumento na geração de receitas, por consequência elemento de equilíbrio das contas públicas. 
Como arremate da abordagem proposta, os critérios de sustentabilidade corroboram com as ideias aqui defendidas, seja nas acepções ambientais e sociais, seja no aspecto econômico, o que serve como reforço na implementação de um modelo de gestão dos bens públicos valorizadora das suas utilidades e da função econômica, sem olvidar a premente questão da solidariedade intergeracional.

\section{Referências}

ABE, Nilma de Castro. Notas sobre a inaplicabilidade da função social à propriedade pública. Revista Brasileira de Direito Constitucional, n. 11, jun. 2008. Disponível em: http://bdjur.stj.jus.br/dspace/handle/2011/34731. Acesso em: 20 dez. 2019.

CARVALHO FILHO, José dos Santos. Manual de direito administrativo. 26. ed. rev., ampl. e atual. São Paulo: Atlas, 2013.

CRISTÓVAM, José Sérgio da Silva. Administração Pública democrática e supremacia do interesse público: novo regime jurídico-administrativo e seus princípios constitucionais estruturantes. Curitiba: Juruá, 2015.

CRISTÓVAM, José Sérgio da Silva; PRIESS, Alexandre dos Santos. O Plano Diretor como instrumento de planificação das cidades: uma análise das consequências jurídicas da sua não revisão e os eventuais impactos da Lei n. ${ }^{\circ}$ 13.655/18 (LINDB). In. VALIATI, Thiago Priess; HUNGARO, Luis Alberto; CASTELLA, Gabriel Morettini e. A Lei de Introdução e o direito administrativo brasileiro. Rio de Janeiro: Lumen Juris, 2019. p. 569-594.

DI PIETRO, Maria Sylvia Zanella. Direito administrativo. 29. ed. Rio de Janeiro: Forense, 2016.

DI PIETRO, Maria Sylvia Zanella. Função social da propriedade pública. Revista Eletrônica de Direito do Estado. Salvador: Instituto de Direito Privado da Bahia, ${ }^{\circ}$ 6, abril/maio/junho de 2006. Disponível em: http://www.direitodoestado.com.br/codrevista.asp?cod=104. Acesso em: 20 dez. 2019.

FREITAS, Juarez. Sustentabilidade: direito ao futuro. 3. ed. Belo Horizonte: Fórum, 2016.

GROSSI, Paolo. Mitologias jurídicas da Modernidade. Tradução de Arno Dal Ri Júnior. Florianópolis: Fundação Boiteux, 2004.

MARQUES NETO, Floriano de Azevedo. Bens públicos: função social e exploração econômica: o regime jurídico das utilidades públicas. Belo Horizonte: Fórum, 2014.

OTERO, Paulo. Manual de direito administrativo. Coimbra: Almedina, 2016.

REIS, João Emilio de Assis. A função social da propriedade e sua aplicabilidade sobre bens públicos. XXI Encontro Nacional do CONPEDI, 2012, Uberlândia. Anais do XXI Encontro Nacional do CONPEDI. Disponível em:

http://www.publicadireito.com.br/artigos/?cod=4d5b995358e7798b. Acesso em: 20 dez. 2019.

ROULAND, Norbert. Nos confins dos Direito: antropologia jurídica da Modernidade. Tradução de Maria Ermantina de Almeida Prado Galvão. São Paulo: Martins Fontes, 2003. 
SAAD, Amauri Feres. Permuta de bens públicos imóveis. Revista de Direito

Administrativo, Rio de Janeiro, v. 265, p.111-147, jan. / abr. 2014. Disponível em:

http://bibliotecadigital.fgv.br/ojs/index.php/rda/article/view/18914. Acesso em: 20 dez. 2019.

SADDY, André; MOURA, Emerson. A natureza jurídica dos bens das empresas estatais brasileiras: análise da controvérsia acerca do controle dos recursos repassado. Revista Digital de Derecho Administrativo, n. 22, p. 141-161, jul./dic. 2019. Disponível em: https://papers.ssrn.com/sol3/papers.cfm?abstract_id=3413771. Acesso em: 20 dez. 2019.

SILVA, José Afonso da. Curso de direito constitucional positivo. 32. ed. rev. e atual. São Paulo: Malheiros, 2009.

STONE, Christofer D.. Should trees have standing? law, morality and the environment. 3. ed. Oxford: Oxford University Press, 2010.

WALD, Arnoldo. Bens públicos: usucapião de imóveis dominicais. Revista de Direito Administrativo, Rio de Janeiro, v. 101, n. 1, p.378-382, jan. 1970. Disponível em: http://bibliotecadigital.fgv.br/ojs/index.php/rda/article/view/34519. Acesso em: 20 dez. 2019. 